\title{
BIMBINGAN DAN PELATIHAN TENTANG PENGEMBANGAN KEPRIBADIAN DAN ETIKA PADA ANGGOTA PKK RW 01 KELURAHAN JATIMULYO KECAMATAN LOWOKWARU KOTA MALANG
}

\author{
Mahmudatul Himmah ${ }^{1}$, Diana Eka Poernamawati ${ }^{2}$, Lilies Nur Ainie ${ }^{3}$, Eko Boedhi Santoso ${ }^{4}$ \\ 1,2,3,4 Jurusan Administrasi Niaga, Politeknik Negeri Malang \\ e-mail: ${ }^{1}$ mahmudatul.himma@polinema.ac.id
}

\begin{abstract}
Abstrak
Kegiatan pengabdian kepada masyarakat ini bertujuan untuk memberikan bimbingan dan pelatihan tentang pentingnya pengembangan kepribadian kepada masyarakat khususnya kaum wanita yang terorganisasi dalam kegiatan sosial kemasyarakatan khususnya kelompok PKK. Sesuai dengan tujuan dari organisasi ini adalah untuk memberikan pendidikan kesejahteraan keluarga dan masyarakat secara intensif agar para ibu-ibu sebagai pendidik paling pertama di keluarga dan anakanaknya dirumah serta lingkungan masyarakat pada umumnya

Metode yang digunakan dalam kegiatan pengabdian ini adalah ceramah dan tanya jawab, yaitu penyampaian materi tentang karakter kepribadian dan cara mengembangkannya. Selain ceramah juga dilakukan diskusi dan Tanya Jawab untuk memberikan kesempatan kepada peserta dalam memahami lebih lanjut tentang materi yang disampaikan. Hasil dari kegiatan ini adalah bahwa para peserta memperoleh wawasan dan pemahaman (kognisi) tentang pentingnya etika dan cara mengembangkan diri khususnya dalam menghadapi perkembangan kehidupan di era globa ini, sehingga dapat menerapkan kepribadian yang efektif dalam kehidupan sehari-hari dan mudah beradaptasi dengan perkembangan teknologi.
\end{abstract}

Kata kunci-Pelatihan, Pengembangan, Kepribadian

\section{PENDAHULUAN}

$P$ erkembangan teknologi dan informasi dewasa ini semakin pesat, dunia seakan begitu dekat dan tanpa batas, arus globalisasi begitu deras mengalir tanpa terbendung. Begitu juga dengan negara Indonesia yang merupakan bagian dari masyarakat dunia mau tidak mau pun merasakan dampak baik secara positif maupun negatif, yang diakibatkan oleh adanya berbagai perubahan yang terjadi. Hal ini menimbulkan permasalahan yang tidak bisa dihindari. Masalah-masalah ini beragam jenisnya, mulai dari masalah sosial, ekonomi, politik, pendidikan, dan lain sebagainya. Bukan hanya orang dewasa yang mengalami masalah- masalah hidup seperti ini, anak-anak dan remaja pun juga mengalami hal tersebut
Masalah ini terjadi karena kepribadian atau karakter dalam diri masyarakat yang kian terkikis oleh kemajuan zaman yang kian pesat, sementara masyarakat tidak sanggup untuk membentengi diri dari perubahan tersebut. Kepribadian itu berasal dari diri setiap individu manusia. Manusia yang memiliki karakter yang baik serta kuat, akan mampu bertahan. Sebaliknya manusia yang tidak mempunya karakter diri akan hanyut dan terseret arus peradaban yang kian maju.

Untuk memperkokoh karakter itu, manusia harus mampu menemukan jalan kebenaran dan selalu ingat kepada Tuhan semesta alam serta menahan diri dari nafsu yang menyesatkan. Di sinilah perlu diterapkannya pendidikan karakter pada setiap individu. Pendidikan karakter ini harus diterapkan secara menyeluruh, artinya sekolah 
agama yang ada di masyarakat, orang tua, lingkungan masyarakat, pemerintah, dan melalui media social.

Kenyataannya banyak hambatan yang dihadapi dalam menanamkan pendidikan karakter ini. Hambatan utamanya adalah pendidikan karakter hanya berhenti pada teori, dan tidak sampai pada praktek dan kebiasaan hidup, kemudian, tidak semua warga di sekolah terlibat. Guru, kepala sekolah, yayasan, dan pegawai seluruh sekolah tidak terlibat dalam pendidikan karakter. Orang tua tidak diikutkan dalam pendidikan ini. Lingkungan masyarakat dan pimpinan masyarakat banyak yang hidup bertentangan dengan nilai karakter yang ditekankan. Hal ini menjadi contoh tidak baik dalam pengembangan karakter orang muda. Oleh karena itu, generasi lama harus membantu generasi muda untuk membentuk karakter atau perilaku yang baik, sehingga membantu terwujudnya masa depan mereka yang lebih cerah.

Demikian juga di RW 01 tidak terlepas dari masalah tersebut, masalah sosial, ekonomi, pendidikan juga menjadi pemasalahan yang perlu diselesaikan. Pendidikan dan pelatihan pengembangan kepribadian merupakan salah satu sarana jalan keluar untuk membentuk karakter dan kepribadian manusia yang kokoh. karakter yang sudah dibentuk sedemikian rupa melalui proses yang baik dan benar, melalui pendidikan dan pelatihan baik itu di rumah, di lembaga pendidikan, ataupun di lingkungan bermasyarakat akan menjadi kokoh dan dapat membentengi diri dari segala hal yang buruk serta mampu dalam menghadapi tantangan yang semakin berat.

Tujuan dari Pengabdian Masyarakat ini adalah untuk menemukan alternatif pembinaan yang tepat guna melalui:

a. Meningkatkan pemahaman pengetahuan tentang etika dan pengembangan karakter/ kepribadian serta dapat menerapkannya dalam kehidupan sehari-hari.

b. Menciptakan peluang menjalin hubungan yang baik dengan masyarakat dalam rangka meningkatkan kesejahteraan keluarga dan lingkungan sekitar. c. Menjalin hubungan yang baik antara Politeknik Negeri Malang dengan masyarakat dan lembaga pendukung.

Rencana aksi yang akan dilakukan dalam kegiatan ini adalah memberikan wawasan dan landasan bagi masyarakat mengenai pentingnya pengembangan kepribadian yang efektif dengan menyampaikan materi, diskusi, tanya jawab, serta studi kasus, serta meyakinkan bahwa sebagai seorang ibu, mengembangkan kepribadian diri adalah hal yang sebaiknya dilakukan mengingat peran ganda seorang ibu yaitu sebagai ibu, sebagai istri dan sebagai anggota masyarakat.

\section{TINJAUAN PUSTAKA}

\subsection{Pengertian Kepribadian}

Menurut Horton (1993) Kepribadian adalah keseluruhan sikap, perasaan, ekspresi dan temperamen seseorang. Sikap perasaan ekspresi dan tempramen itu akan terwujud dalam tindakan seseorang jika di hadapkan pada situasi tertentu. Setiap orang mempunyai kecenderungan perilaku yang baku, atau pola dan konsisten, sehingga menjadi ciri khas pribadinya. Sedangkan menurut Derlega, et all dalam Yusuf \& Nurihsan (2008 : 3) Kepribadian adalah sistem yang relatif stabil mengenai karakteristik individu yang bersifat internal, yang berkontribusi terhadap pikiran, perasaan, dan tingkah laku yang konsisten".

Berdasarkan pengertian tersebut dapat ditarik kesimpulan kepribadian merupakan tingkah laku atau sifat seseorang yang khas yang terbentuk dari diri sendiri ataupun lingkungan.

Kepribadian

Pengertian Pengembangan

Andrew F. Sikula mendefinisikan pengembangan sebagai berikut: "Pengembangan mengacu pada masalah staf dan personel adalah suatu proses pendidikan jangka panjang menggunakan suatu prosedur yang sistematis dan terorganisasi dengan mana manajer belajar pengetahuan konseptual dan teoritis untuk tujuan umum".

Pengembangan kepribadian berarti kemauan diri sendiri untuk menata aspek internal diri atau sikap batin, dan aspek perilaku eksternal diri, yaitu cara seseorang 
menampilkan diri atau tampak sisi luar diri di persepsi orang lain. (Djajendra, 2011:312)

\subsection{Faktor-faktor Pembentuk Kepribadian}

Kepribadian atau sifat kekhasan dari seseorang sangatlah dipengaruhi oleh beberapa faktor yang akan membentuk suatu kebudayaan. Menurut (Horton, 1993),

Pembentukan kepribadian seseorang berlangsung dalam suatu proses yang disebut dengan sosialisasi, yaitu suatu proses dengan mana seseorang menghayati (mendarahdagingkan-internalize) norma-norma

kelompok dimana ia hidup sehingga muncullah dirinya yang "unik".

Faktor-faktor yang memiliki peran dalam pengembangan kepribadian seseorang meliputi beberapa faktor sebagai berikut:

1. Waarisan Biologis (Heredity)

Warisan biologis berpengaruh pada perilaku kehidupan manusia, misalnya pada pembentukan sifatkepemimpinan, pengendalian diri, sikap, dan minat. Setiap manusia memiliki sifat biologis yang berbeda antara satu dengan yang lainnya, walaupun pada dua orang lahir kembar identik. Adanya perbedaan jenis kelamin, kecerdasan, kekuatan jasmani, kecantikan, dan sebagainya akan dapat berpengaruh pada perbedaan kepribadian orang- orang yang memilikinya. Banyak ilmuwan berpendapat bahwa perkembangan potensi warisan biologis dipengaruhi oleh pengalaman seseorang. Bakat yang dimiliki seseorang memerlukan anjuran, pengarahan, dan latihan untuk mengembangkan diri melalui kehidupan bersama dengan manusia lain.

2. Warisan Lingkungan Alam (Natural Environment)

Perbedaan iklim, topografi, dan sumber daya alam menyebabkan manusia harus mampu menyesuaikan diri dengan lingkungan alam di mana ia tinggal. Proses penyesuaian diri pada lingkungan alam mampu mengubah pola perilaku masyarakat secara keseluruhan.

3. Warisan Sosial (Social Herritage) atau kebudayaan

Manusia, alam, dan kebuadayaan mempunyai hubungan yang sangat erat dan saling memengaruhi. Sementara itu, kebudayaan sangat berpengaruh pada perilaku individu dalam pembentukan kepribadiannya. \begin{tabular}{lcr}
\multicolumn{1}{r}{ Manusia } & sebagai & makhluk yang \\
berpikir akan & senantiasa & menghasilkan \\
kebudayaan & sebagai & manifestasi
\end{tabular} kehidupannya. Manusia berusaha untuk mengubah alam sesuai dengan kebudayaannya guna memenuhi kebutuhan hidupnya. Selain itu, manusia dapat mengubah pegunungan menjadi lahan pemukiman.

4. Pengalaman hidup dalam kelompok

Sebagai makhluk sosial, manusia senatiasa hidup dalam kelompok-kelompok, seperti keluarga, RT, dan sekolah. Dengan demikian, kehidupannya akan dipengaruhi oleh kelompok tersebut. Hal ini mengingat setiap kelompok pasti memiliki norma, nilai, dan aturan sendiri yang berbeda dengan kelompok lain.

Setiap kelompok pasti memengaruhi anggota- anggotanya. Setiap kelompok pasti mewariskan pengalaman khas yang tidak diberikan kelompok lain, sehingga akan muncul kepribadian khas anggota kelompok tersebut.

Kelompok yang menjadi acuan pertama seorang anak adalah keluarga. Pengalaman hidup dalam keluarga sangat menentukan perkembangan kepribadian seorang anak. Seorang anak yang hidup dalam keluarga yang demokratis, akan tumbuh menjadi orang dengan kepribadian baik dan percaya diri.

\subsection{Karateristik Kepribadian}

Setiap kepribadian selalu memiliki karakteristik berbeda, tidak semua individu mampu menampilkan secara wajar, normal, atau sehat banyak diantaranya mengalami secara tidak sehat. Menurut Hurlock dalam Yusuf \& Nurihsan (2008 :

12) mengemukakan bahwa krakterisrik penyesuaian yang sehat atau kepribadian yang sehat (healthy personality) ditandai dengan :

1. Mampu menilai diri secara realistik, individu yang kepribadianya sehat mampu menilai diri apa adanya, baik kelebihan maupun kelemahannya menyangkut fisik (postur tubuh, wajah, keutuhan, dan kesehatan) dan kemampuan (kecerdasan dan ketrampilan).

2. Mampu menilai situasi secara realistik. Individu dapat menghadapi situasi atau kondisi kehidupan yang dialaminya secara realistik dan mau 
menerimanya secara wajar. Dia

tidak mengharapkan kondisi.

Kehidupan itu sebagai suatu yang harus sempurna.

3. Mampu menilai prestasi yang diperoleh secara realistik. Individu dapat menilai prestasinya (keberhasilan yang diperolehnya) secara realistik dan reaksinya secara rasional. Dia tidak menjadi sombong, angkuh atau mengalami "superiority complex", apabila memproleh prestasi yang tinggi, atau kesuksesan dalam hidupnya. Apabila mengalami kegagalan, dia tidak mereakisnya dengan frustasi, tetapi dengan sikap potimistik (penuh harapan).

4. Menerima tanggung jawab. Individu sehat adalah individu yang beranggung jawab. Dia memiliki keyakinan terhadap kemampuannya untuk mengatasi masalah - masalah kehidupan yang dihadapinya.

5. Kemandirian (autonomy). Individu memiliki sifat mandiri dalam cara berpikir dan bertindak, mampu mengambil keputusan, mengarahkan dan mengembangkan diri serta menyesuaikan diri dengan norma yang berlaku di lingkungannya.

6. Dapat mengontrol emosi. Individu merasa nyaman dengan emosinya. Dia dapat menghadapi situasi frustasi, depresi atau stres secara positif atau konstruktif, tidak destruktif (merusak).

7. Berorientasi tujuan. Setiap orang mempunyai tujuan yang ingin dicapainya. Namun, dalam merumuskan tujuan itu ada yang realistik dan ada yang tidak realistik. Individu yang sehat kepribadiannya dapat merumuskan tujuannya berdasarkan pertimbangan secara matang (rasional), tidak atas dasar paksaan dari luar. Dia berupaya untuk mencapai tujuan tersebut dengan cara mengembangkan kepribadian wawasan) dan ketrampilan.

8. Berorientasi keluar. Individu yang sehat memiliki orientasi keluar (ekstrovert). Dia bersifat respek (hormat), empati terhadap orang lain mempunyai kepedulian terhadap situasi, atau masalah - masalah lingkungannya dan bersifat fleksibel dalam berpikir. Barrat Leonard mengemukakan sifat -sifat individu dan menilai orang lain seperti menghargai dan menilai orang lain seperti dirinya sendiri, merasa nyaman dan terbuka terhadap orang lain, dan tidak membiarkan dirinya dimanfaatkan untuk menjadi korban orang lain dan tidak mengorbankan orang lain karena kekecewaan dirinya.

9. Penerimaan sosial. Individu dinilai positif oleh orang lain mau berpartisipasi aktif dalam kegiatan sosial, dan memiliki sikap bersahabat dalam berhubungan dengan orang lain.

10. Memiliki filsafat hidup. Dia mengarahkan hidupnya berdasarkan filsafat hidup yang berakar dari keyakinan agama yang dianutnya.

11. Berbahagia. Individu yang sehat, situasi kehidupannya diwarnai kebahagiaan. Kebahagiaan didukung oleh faktor - faktor achievement (pencapaian prestasi), acceptance (penerimaan dari orang lain), dan affection (perasaan dicintai atau disayangi orang lain).

\section{METODE}

\subsection{Metode PKM}

Metode yang digunakan dalam kegiatan PKM ini adalah tatap muka dengan cara:

a. Ceramah

Alih pengetahuan diberikan dengan metode ceramah, yaitu penyampaian materi yang sesuai dengan bimbingan yang dilaksanakan serta dengan memberikan contoh-contoh dalam bentuk slide mengenai karakter kebribadian dan cara mngembangkannya.

b. Diskusi dan Tanya Jawab

Dilaksanakan untuk memberikan ruang kepada khalayak sasaran dalam memahami lebih lanjut tentang materi yang disampaikan serta membantu membangun hubungan yang lebih erat antara pelaksana PKM dan khalayak sasaran.

c. Pembahasan Masalah 
Dalam kegiatan ini pelaksana PKM terlibat secara langsung membantu para peserta dalam memahami materi dengan benar, memilih kata sesuai dengan bahasa Indonesia yang sesuai dengan ejaan yang disempurnakan, menjaga situasi tetap formal, pemilihan bahasa yang tegas, lugas tapi sopan, terutama bagaimana mengajarkan dan memberi contoh tanpa menggurui.

\subsection{Rancangan Evaluasi}

1. Evaluasi Sebelum Kegiatan

Sebelum melaksanakan kegiatan dilakukan observasi pendahuluan, membuat persiapan materi dan media, agar kedua hal yang telah dirancang bisa diterima oleh peserta.

2. Evaluasi Selama Kegiatan

Selama melakukan kegiatan, dilakukan evaluasi sebagai berikut:

a. Evaluasi terhadap kehadiran peserta dan kesiapan tempat serta ketersediaan bahan- bahan ajar, fasilitas dan tata ruang

b. Evaluasi hambatan baik masalah penyampaian materi maupun hal-hal yang bersifat teknis.

b. Evaluasi kelayakan materi yang diberikan.

c. Evaluasi daya penerimaan materi peserta/ penyerapan materi.

3. Evaluasi terhadap kemampuan para peserta.

4. Evaluasi akhir kegiatan

\section{HASIL DAN PEMBAHASAN}

Kegiatan PKM ini berbentuk pelatihan dan pemberian wawasan kepada peserta.

Adapun tujuan dari pengabdian ini adalah untuk meningkatkan wawasan ibu-ibu anggota PKK tentang pentingnya pengembangan kepribadian baik untuk diri sendiri dan maupun keluarga. Dengan metode yang digunakan yaitu ceramah, diskusi dan tanya jawab, serta analisa dan pemecahan kasus, diharapkan dengan selesainya kegiatan pengabdian ini, ibu-ibu dapat menerapkan pengembangan kepribadian ini dengan cara mengembangkan diri di segala bidang terutama yang diminati, sehingga akan dicapai tingkat optimisme yang meningkat, pengembangan kreativitas dan inovasi, motivasi yang kuat untuk maju.

Keberhasilan dari Pengabdian kepada masyarakat ini memang belum nampak secara instan, namun melihat semangat ibu-ibu untuk berkembang, maka dapat diyakini akan berproses secara bertahap.

Pelaksanaan kegiatan ini dirasa tidak ada hambatan yang berarti, hal ini mengingat materi yang diberikan sangat familiar dan dimiliki semua manusia. Kepribadian adalah karakter yang dimiliki semua manusia, hanya proses pengembangannya berbeda-beda tergantung faktor situasi dan kondisi lingkungan manusia.

Adapun faktor pendorong dari kelancaran kegiatan ini adalah :

-minat dan semangat para peserta dalam mengikuti kegiatan meski di tengah suasana pandemi, mereka tetap semangat untuk hadir dan mengikuti kegiatan hingga selesai.

- aparat setempat, dalam hal ini pimpinan RW sangat mendukung kegiatan ini dengan memberi izin serta menyediakan tempat dan peralatan pendukung

\section{KESIMPULAN}

Beberapa seimpulan yang dapat diambil pada kegiatan Pengabdian Kepada Masyarakat adalah :

a. Peserta pelatihan kegiatan PKM ini adalah Ibu-ibu Anggota PKK RW 01 Kelurahan Jatimulyo Kecamatan Lowokwaru Malang.

b. Peserta sangat antusias dalam mengikuti kegiatan pelatihan. Hal ini ditunjukkan dengan banyaknya pertanyaan dan respon menjawab ketika diberi pertanyaan

c. Keberhasilan dari kegiatan pengabdian ini memang belum dapat dilihat secara langsung dan keseluruhan. Namum jika dilihat dari hasil yang dicapai maka manfaatnya adalah dengan bertambahnya wawasan dan pengetahuan dapat

- rasa percaya diri yang kuat, 
d. membantu mereka dalam mengembangkan diri dan berkepribadian yang kuat terutama di situasi dan kondisi sekarang yang serba tidak pasti. Untuk itu perlu direncanakan tahapan berikutnya yaitu memonitor dan mengevaluasi hasil dari kegiatan

\section{SARAN}

Saran yang ddisampaikan antara lain :

1. Pelaksanaan PKM hendaknya dilaksanakan secara berlanjut agar pemahaman masyarakat semakin meningkat dan membuahkan kesadaran tentang pentingnya mengembangkan diri dalam kehidupan bermasyarakat

2. Agar supaya ilmu yang diberikan dapat bermanfaat baik bagi diri sendiri maupun masyarakat diharapkan masyarakat khususnya ibu- ibu anggota PKK RW 01 Kelurahan Jatimulyo Kota Malang dapat menerapkan kepribadian yang efektif dalam kehidupan sehari-hari, mudah beradaptasi dengan perkembangan teknologi dan dapat mengajarkan serta memberi teladan yang baik kepada putra putrinya

3. Kegiatan pembimbingan perlu direncanakan secara terprogram dan simultan. Sehingga masing-masing perguruan tinggi termasuk POLINEMA hendaknya menyediakan topik ini untuk disajikan kepada masyarakat melalui kegiatan PKM

\section{DAFTAR PUSTAKA}

Fahmi, Irham. 2016. Manajemen Sumber Daya Manusia. Bandung: Alfabeta

Horton, Paul, B. 1993. Sosiologi Jilid 1, Bandung, Erlangga

Mangkunegara, A.A Anwar Prabu. 2013. Manajemen Sumber Daya Manusia Perusahaan.Bandung: PT Remaja Rosdakarya

Winarti Euis, 2007. Pengembangan kepribadian. Surabaya :Graha Ilmu.
Yusuf Syamsu \&Juntika A Nurihsan.2008. Teori Kepribadian. Bandung: PT Remaja Rosdakarya Offset. 